OPEN ACCESS

Citation: F. Fallah, F. Ghahremaninejad (2021) Ploidy level determination of Hedera (Araliaceae) with an emphasis on discussable species (Hedera hibernica). Caryologia 74(1): 109-116. doi: 10.36253/caryologia-881

Received: March 19, 2020

Accepted: October 02, 2020

Published: July 20, 2021

Copyright: (c) 2021 F. Fallah, F. Ghahremaninejad. This is an open access, peer-reviewed article published by Firenze University Press (http://www. fupress.com/caryologia) and distributed under the terms of the Creative Commons Attribution License, which permits unrestricted use, distribution, and reproduction in any medium, provided the original author and source are credited.

Data Availability Statement: All relevant data are within the paper and its Supporting Information files.

Competing Interests: The Author(s) declare(s) no conflict of interest.

ORCID

FF: 0000-0003-0165-1369

FG: 0000-0001-5860-9976

\section{Ploidy level determination of Hedera (Araliaceae) with an emphasis on discussable species (Hedera hibernica)}

\author{
Fahimeh Fallah, Farrokh Ghahremaninejad ${ }^{*}$ \\ Department of Plant Sciences, Faculty of Biological Sciences, Kharazmi University, Teh- \\ ran, Postal Code 15719-14911, Iran \\ ${ }^{\star}$ Corresponding author. E-mail: fgh@khu.ac.ir
}

\begin{abstract}
Genome size is a helpful tool for circumscribing taxa at diverse taxonomic degrees (mostly species) and resolving intricate low-level taxonomies. The correct genome size in Hedera (Araliaceae) has long been discussed, and the ploidy levels of some taxa are still unclear. Twelve accessions of Hedera were measured via flow cytometry. Flow cytometry is a relatively rapid, inexpensive, and credible tool. Fresh leaves of Hedera samples and internal reference standard parsley (Petroselinum crispum) were stained with propidium iodide (PI). Flow cytometry measurements showed that for the accessions of $2 \mathrm{CV}$ (3.09 - $6.40 \mathrm{pg}$ ), the lowest amount of nuclear DNA was $3.09 \mathrm{pg}$ for Hedera crebrescens (So), while the highest amount was $6.40 \mathrm{pg}$ for $H$. hibernica "Hamilton," representing a statistically significant difference. According to this study, the new taxon (H. crebrescens) is a diploid, though this taxon was previously considered $H$. hibernica (tetraploid).
\end{abstract}

Keywords: flow cytometry, Petroselinum crispum, genome size, Hedera crebrescens.

\section{INTRODUCTION}

Hedera L. is an evergreen woody vine native to Europe, Asia, and North Africa, but it is cultivated worldwide (Rose 1996; Reichard 2000; Ackerfield and Wen 2002, 2003). The taxonomic history of the Hedera taxa is complicated because of its two-part life cycle, extensive geographic distribution. Juvenile phase with palmately lobed leaves on steril stems and adult phase with unlobed cordate adult leaves on fertile flowering stems. The juvenile and adult shoots also differ, the juvenile being slender, pliable and scrambling or climbing with small aerial roots to fix the shoot to the substrate (rock or tree bark), the adult shoots thicker and without aerial roots. (Rose 1996; Rutherford et al. 1993; Ackerfield and Wen 2002).

Taxonomic recognition was first afforded to juvenile and adult plants, which were described by Linnaeus (1753) as "H. helix L." and "H. arborea (L.) Walter." A previous investigation on Hedera recognized five species (Lawrence and Schulze 1942). However, later studies on Hedera have suggested that these five species should be subdivided into more species (Ackerfield 2001). 
Furthermore, a key to the classification of species and subspecies of Hedera has been derived based on trichome and leaf morphology (Ackerfield and Wen 2002). Recently the European Garden Flora has reported that there are 12 Hedera taxa (McAllister and Marshall 2017). However, the definition of species and identification of taxa are still disputed (Valcárcel and Vargas 2010).

Since ancient times, many Hedera cultivars have been used in Europe for cover green and garden decorations (Rose 1996) and a remarkable number of cultivars have been identified as H. hibernica (G. Kirchn.) Bean and H. helix subsp hibernica (G. Kirchn.) (D.C. McClinton). Based on differences in trichome positioning, leaf form, and chromosome number, $H$. hibernica has been recognized (McAllister and Rutherford 1990) as a distinct species from H. helix. It has been reported (McAllister and Rutherford 1990; Jacobsen 1954) that H. helix and $H$. hibernica have different chromosome numbers, with $H$. helix being diploid $(2 \mathrm{n}=48)$ and $H$. hibernica being tetraploid $(2 \mathrm{n}=96)$.

$H$. hibernica was thought to be a unique tetraploid species, and hence, it was carefully compared with a typical diploid $H$. helix. However, recent molecular data indicate that $H$. helix and $H$. hibernica may represent differrent species (Metcalfe 2005). H. helix (diploid) has been the maternal parent for the tetraploid $H$. hibernica (Ackerfield and Wen 2003). Sometimes, diploid and polyploid species of the Hedera genus are barely distinct morphologically or through DNA sequencing data (Green et al. 2011). The taxonomic and evolutionary significance of variations in genome size has been established, and chromosomal data are extensively used in plant taxonomy (Stace 2000; Kron et al. 2007; Ekrt et al. 2009). Increasing ploidy usually results in increased cell size. Plants with increased ploidy levels may be appa- rently distinct morphologically.

Flow cytometry is a very useful tool for measuring DNA content and can be related to the ploidy level for a specified taxon (Sharma and Sharma 1999). Although genome size in Hedera has long been disputed, the genomic DNA amounts of many taxa are still unknown (Domoney and Timmis 1980; Polito and Alliata 1981; Konig et al. 1987).

However, molecular studies based on flow cytometric measurements have revealed that polyploidy has been significant to the evolution of the Hedera species and might have taken place many times independently in various lineages (Green et al. 2011).

Recent reports have indicated that some taxa with different morphological and cytological characteristics are spreading in semi-natural habitats and urban areas that contain escaped gardens (Udvardy and Bényei-Himmer 1999).
Recently, by studying ivy diversity in Hungary, researchers have identified a prominent Hedera taxon that has a particular habit, contains a set of distinguishable morphological and phonological features, and has various environmental demands. Previously, this was thought to be H. hibernica (Bényei-Himmer et al. 2017). However, Bényei and Höhn (2017) recently identified this taxon as $H$. crebrescens. The purpose of the present study was to use flow cytometry measurements to clarify the situation of the Hedera taxa that is spread- ing in Hungary and other countries in central Europe, was previously identified as $H$. hibernica, and has been recently identified as $H$. crebrescens.

\section{MATERIALS AND METHODS}

Hedera specimens were collected from different natural habitats in Central Europe and from the Soroksár Botanical Garden of Budapest (Fig. 1). Genome size was examined by flow cytometery. Following Ramsey (2007) completely expanded fresh leaf tissues from each sample $(0.5 \mathrm{~g})$ were manually chopped with a sharp razor blade for approximately $1 \mathrm{~min}$ in petri dish with the same amount of leaf tissue from diploid Petroselinum crispum (Apiaceae) as an internal reference standard (Fig. 2), in $2 \mathrm{~mL}$ of isolation buffer ( $3.6 \mathrm{~g}$ HEPES, $2 \mathrm{~mL}$ of a 0.5 $\mathrm{M}$ solution of EDTA, $6.0 \mathrm{~g} \mathrm{KCL}, 1.2 \mathrm{~g} \mathrm{Na} \mathrm{Cl}, 102.7 \mathrm{~g}$ sucrose, $2 \mathrm{~mL}$ Triton X-100, $1 \mathrm{~mL}$ ß-mercaptoethanol, and $0.1 \mathrm{~g}$ spermine in $1.0 \mathrm{~L}$ distilled water). Following that, nuclear suspension was filtered through a nylon mesh $(25 \mu \mathrm{m})$ to remove debris and then stained with Propidium Iodide (PI) at a final density $100 \mu \mathrm{g}$. $\mathrm{mL}^{-1}$ and complemented with $100 \mu \mathrm{g}$. $\mathrm{mL}^{-1}$ ribonuclease A (RNAs). 1C-value was calculated based on the converting formula (Dolezel et al. 2003) [1pg=978 mega base pairs (Mbp)].

The relationship between mean $(n=3) 2 C$-values of leaf samples were processed and the resulting fluorescence histograms were analyzed with Flomax Software. The total DNA amount of a sample was calculated based on the values of the G1 peak means as follows (Dolezel et al. 2003, 2007; Dolezel and Bartos 2005.) (Sample 2C DNA (pg) content $=[($ Sam- ple G1 peak mean) $/($ Standard G1 peak mean)]×2C DNA amount Standard).

\section{RESULTS AND DISCUSSION}

As presented in Table 1, 12 taxa of Hedera genus were evaluated by Partech Flomax software Ver. 2.0.01 in order to assess the nuclear DNA contents (pg) and genome sizes (Mbp). Among 8 diploids examined, the 

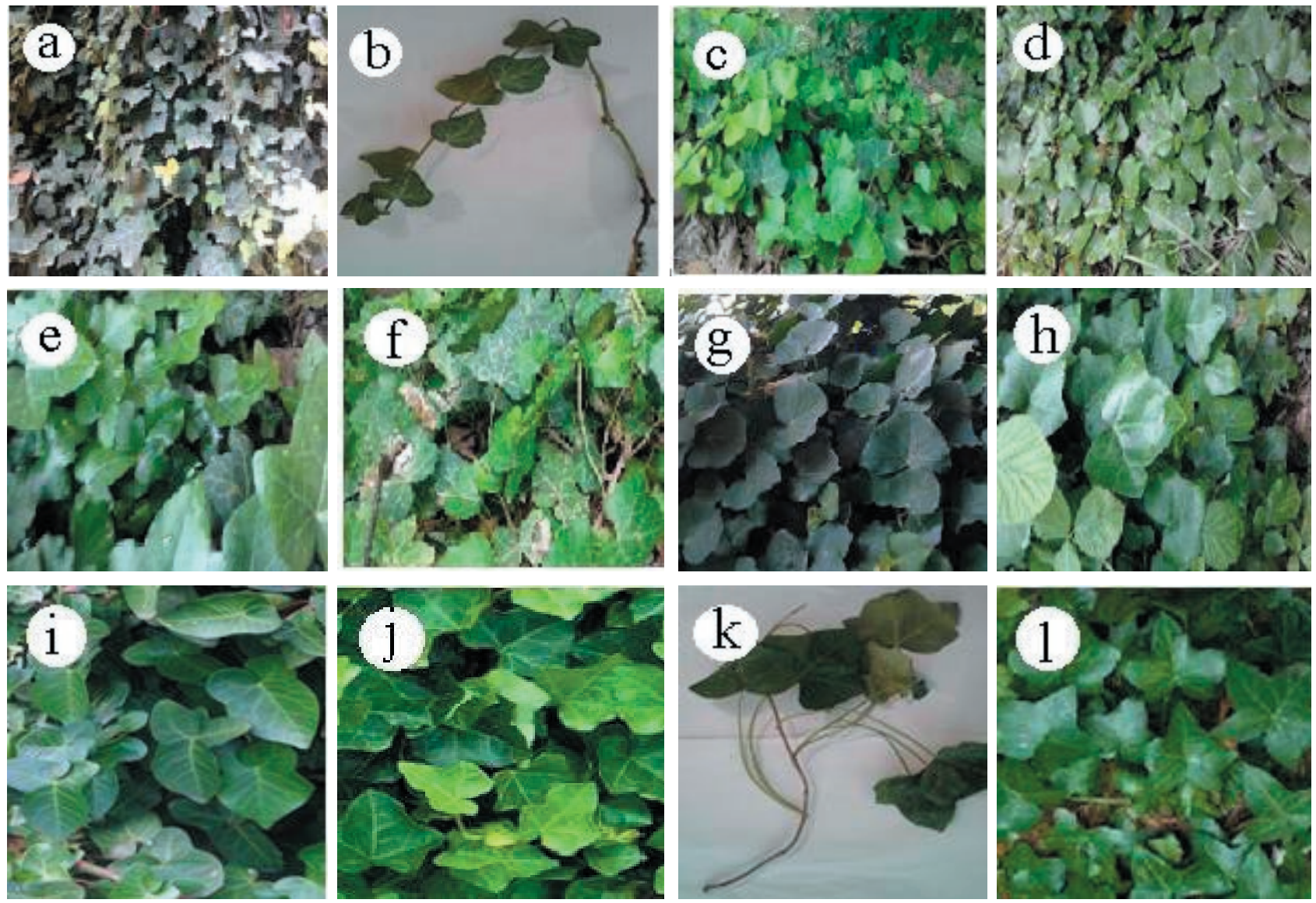

Figure 1. Images of Hedera species analysed in this study: a,b: H. helix, c: H. helix arborescence, d,e: H. hibetnica, f: H. hibernica arborescence, g,h: H. crebrescens, i: H. hibernica "Deltoiedea", j, k: H. hibernica" Variegata", 1: H. hibernica "Hamilton".

lowest amount of nuclear DNA was 3.09 pg for $\mathrm{H}$. crebrescens (So) and $3.33 \mathrm{pg}$ for the H. crebrescens $(\mathrm{JH})$. As a result, a statistically insignificant difference of $0.24 \mathrm{pg}$ was observed between four tetraploids while a statistically significant difference in $2 \mathrm{C}$-value $(0.64 \mathrm{pg})$ in the range of 5.76-6.40 pg is noticed between $H$. hibernica "Variegata" (5.76 pg) and H. hibernica "Hamilton" (6.40 pg).

Determination of genome size and ploidy level are summarized in (Table 1) and results analyzing the amount of nuclear DNA are shown in (Fig. 3, 4). Sometimes in Hedera species the related diploid and polyploidy are poorly distinct via morphology and DNA sequence data (Green et al. 2011).

Although polyploidy in the Hedera genus is common, the occurrence of auto and allopoly-ploidy is poorly understood (Yi et al. 2004). Trichome morphology and leaf shape analyses revealed that $H$. hibernica is an allopolyploid from $H$. helix and $H$. maroccana (McAllister and Rutherford 1990). Furthermore, based on nucleotide polymorph isms in nrDNA (ITS) H. hibernica was recognized as an allopolyploid (Vargas et al. 1999). It has commonly been believed that internal reduplication is correlated with very small genomes, assuming that minimal DNA content is needed for suitable cell functioning. In fact, taxonomists have surely realized that some related species with the same number of chromosomes might be different in terms of DNA volume, thus making them easily distinctive by using flow cytometry.

Recent studies on vascular plants revealed only a weak negative correlation between genome size and degree of polyploidyization (Barow and Meister 2005). Thus, C-values should be treated as a fundamental scaling factor in living systems (Bennett et al. 2000).

The specimens examined in the present work by flow cytometry measurements showed that the accessions 2C-value (3.06-6.40 pg) veryfying more than a two-fold variation and showing a corresponding genome size of 1516-3129 Mbp. Among the eight examined diploids, the lowest amount of nuclear DNA was $3.09 \mathrm{pg}$ (for H. crebrescens (So)), while the highest amount was 
Table 1. Samples, locality and determination of genome size and ploidy level.

\begin{tabular}{|c|c|c|c|c|c|c|c|c|}
\hline Samples & Locality & Latitude ( N ) & Longitude ( E ) & $\begin{array}{c}\text { Ploidy } \\
\text { level }\end{array}$ & $\begin{array}{c}\text { Mean 2C } \\
\text { value level } \\
(\text { pg } \pm \text { SE) }\end{array}$ & $\begin{array}{c}\text { Mean } 1 C \\
\text { value } \\
(\mathrm{pg})\end{array}$ & $\begin{array}{c}\text { Mean } 1 C \\
\text { value } \\
(\mathrm{Mbp})^{*}\end{array}$ & $\% \mathrm{CV}$ \\
\hline H. helix & Soroksár (Hungary) & N 47²3’ 18.644" & E $19^{\circ} 9^{\prime} 2.165^{\prime \prime}$ & $2 \mathrm{x}$ & $3.16 \pm 0.05$ & 1.58 & 1545.24 & 0.02 \\
\hline H. helix arborescence & Gellért Hill (Hungary) & N 47²9’12.898” & E $19^{\circ} 2^{\prime} 40.23^{\prime \prime}$ & $2 \mathrm{x}$ & $3.16 \pm 0.04$ & 1.58 & 1545.24 & 0.01 \\
\hline H. hibernica & Gellért Hill (Hungary) & N 47²9’12.898” & E $19^{\circ} 2^{\prime} 40.23^{\prime \prime}$ & $4 \mathrm{x}$ & $6.23 \pm 0.30$ & 3.11 & 3041.58 & 0.05 \\
\hline H. hibernica arborescence & Soroksár (Hungary) & N 47²3' 18.644" & E $19^{\circ} 9^{\prime} 2.165^{\prime \prime}$ & $2 \mathrm{x}$ & $3.17 \pm 0.07$ & 1.57 & 1535.46 & 0.02 \\
\hline H. hibernica "Deltoiedea" & Soroksár (Hungary) & N 47²3’ $18.644^{\prime \prime}$ & E $19^{\circ} 9^{\prime} 2.165^{\prime \prime}$ & $4 \mathrm{x}$ & $6.33 \pm 0.12$ & 3.16 & 3090.48 & 0.02 \\
\hline H. hibernica "Hamilton" & Gellért Hill (Hungary) & N 47²9’12.898” & $\mathrm{E} 19^{\circ} 2^{\prime} 40.23^{\prime \prime}$ & $4 \mathrm{x}$ & $6.40 \pm 0.07$ & 3.2 & 3129.6 & 0.01 \\
\hline H. hibernica "Variegata" & Soroksár (Hungary) & N 47²2’ 18.644” & E $19^{\circ} 9^{\prime} 2.165^{\prime \prime}$ & $4 \mathrm{x}$ & $5.76 \pm 0.11$ & 2.88 & 2816.64 & 0.02 \\
\hline H. crebrescens (V) & Vienna (Austria) & N 48²' $31.307^{\prime \prime}$ & E $16^{\circ} 22^{\prime} 21.702^{\prime \prime}$ & $2 \mathrm{x}$ & $3.19 \pm 0.01$ & 1.59 & 1555.02 & 0.01 \\
\hline H. crebrescens $(\mathrm{JH})$ & János Hill (Hungary) & N 4729’ $52.836^{\prime \prime}$ & E $19^{\circ} 2^{\prime} 23.675^{\prime \prime}$ & $2 \mathrm{x}$ & $3.33 \pm 0.12$ & 1.66 & 1623.48 & 0.04 \\
\hline$H$, crebrescens (Sze) & Szeged (Hungary) & N 46º'10'18.332" & E $19^{\circ} 25^{\prime} 22.52^{\prime \prime}$ & $2 \mathrm{x}$ & $3.22 \pm 0.05$ & 1.61 & 1574.58 & 0.02 \\
\hline H. crebrescens (So) & Soroksár (Hungary) & N 47²3’ 18.644" & E $19^{\circ} 9^{\prime} 2.165^{\prime \prime}$ & $2 \mathrm{x}$ & $3.09 \pm 0.07$ & 1.54 & 1506.12 & 0.02 \\
\hline
\end{tabular}

${ }^{\star} 1 \mathrm{pg}=978 \mathrm{Mbp}^{27}$

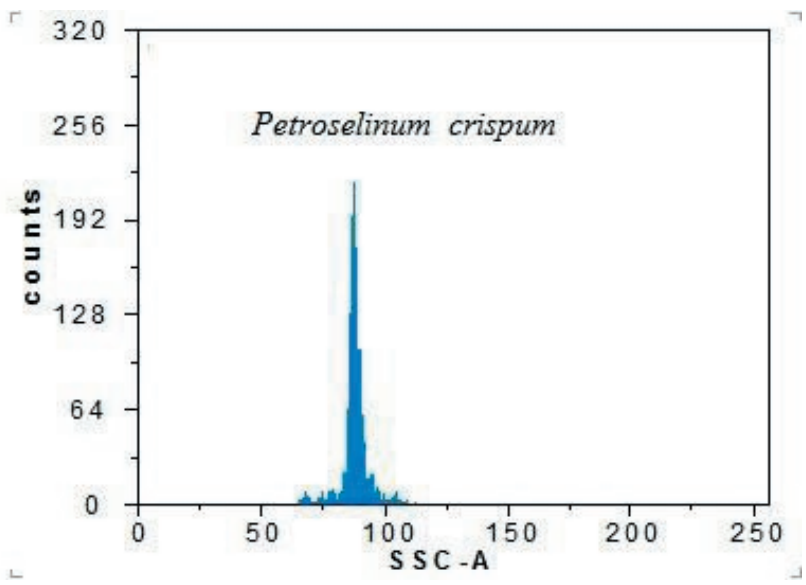

Figure 2. The histogram for analysis of the amount of nuclear DNA in leaves: parsley (P. crispum) reference standard $(2 \mathrm{C} \mathrm{DNA}=4.50 \mathrm{pg})$.

3.33 pg (for $H$. crebrescens $(\mathrm{JH})$ ). Statistically in significant differences were found between four tetraploids. Meanwhile, si- gnificant differences of $0.64 \mathrm{pg}$ in 2Cvalue (ranging from 5.76-6.40 pg) were recognized for $H$. hibernica "Variegata" (5.71 pg) and H. hibernica "Hamilton" (6.40 pg).

The results attained by Marie and Brown (1993) indicate that for $\mathrm{H}$. helix, $2 \mathrm{CV}=8.18 \mathrm{pg}$, which is strongly refuted by the data presented in the current study and stands as an uncom mon value for DNA amounts (Bennett and Leitch 1997). Petunia hybrid Vilm. was used by Marie and Brown (1993) as a standard reference. $H$. helix which studied by Marie and Brown from Stras-
burg-France (Latitude N 48³4'50.959", Longitude E $\left.7^{\circ} 45^{\prime} 49.623^{\prime \prime}\right)$ is not very far from to region we were collected H.helix, According to the present study, the data for H. helix $(2 \mathrm{CV}=4.6 \mathrm{pg})$ reported by Domoney and Timmis (1980) remains unsuported.

As reported previously, $H$. helix $2 \mathrm{CV}=2.95$ (Konig et al. 1987), H. helix $2 \mathrm{CV}=2.80$ (Obermayer and Greilhuber 2000) and $H$. hibernica $2 \mathrm{CV}=6.00$ (Zonneveld et al. 2005), which are close to the present results. The morphometric analyses of $H$. helix, $H$. hibernica "Hamilton" and the new taxon (H. crebrescens) were based on vegetative and generative organs and were conducted to distinguish the new taxon from $H$. helix and $H$. hibernica (Clarke et al. 2006). The genome size, which represents an inherent attribute, is a supportive feature for circumscribing taxa of various taxo- nomic ratings (mainly species) and resolving intricate low-level taxonomies (Loureiro et al. 2006).

The analysis based on flow cytometry indicated that $H$. crebrescens can be considered a distinct taxon among the diploid ivies. According to the present study, which is strongly supported by the notion of a newly identified diploid taxon (Hedera crebrescens) (Bényei and Höhn 2017), it should be emphasized that this taxon which was previously treated as $H$. hibernica is not identical to the tetraploid taxon. 

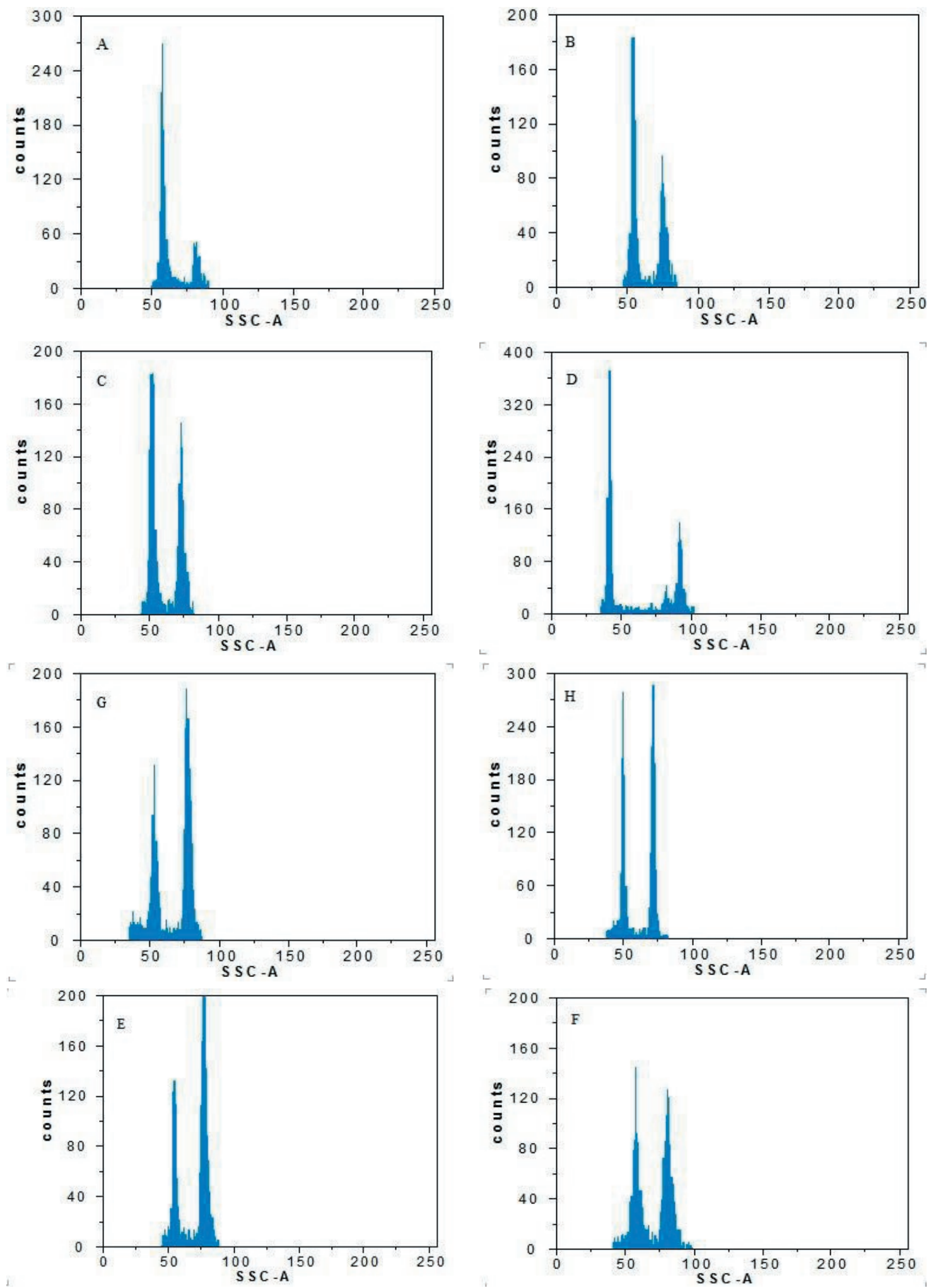

Figure 3. The histogram for analysis of the amount of nuclear DNA in leaves: The left peaks refer to the unknown Hedra samples and the right peaks to the known parsley (P. crispum) reference standard $(2 \mathrm{C} D N A=4.50 \mathrm{pg})$. A: H. crebrescens $(\mathrm{V})=3.19 \mathrm{pg}$. $\mathrm{B}:$ H. crebrescens $(\mathrm{JH})=3.33$ pg, C: $H$ crebrescens $(\mathrm{Sze})=3.22$ pg. D: H. crebrescens $(\mathrm{So})=3.09$ pg. E: H. crebrescens $(\mathrm{GH}) 5=3.16 \mathrm{pg}$. F: H. helix=3.16 pg. G: H. helix arborescence $=3.16 \mathrm{pg}, \mathrm{H}$ : H. hibernica arborescence $=3.17 \mathrm{pg}$, diploids Hedera . 

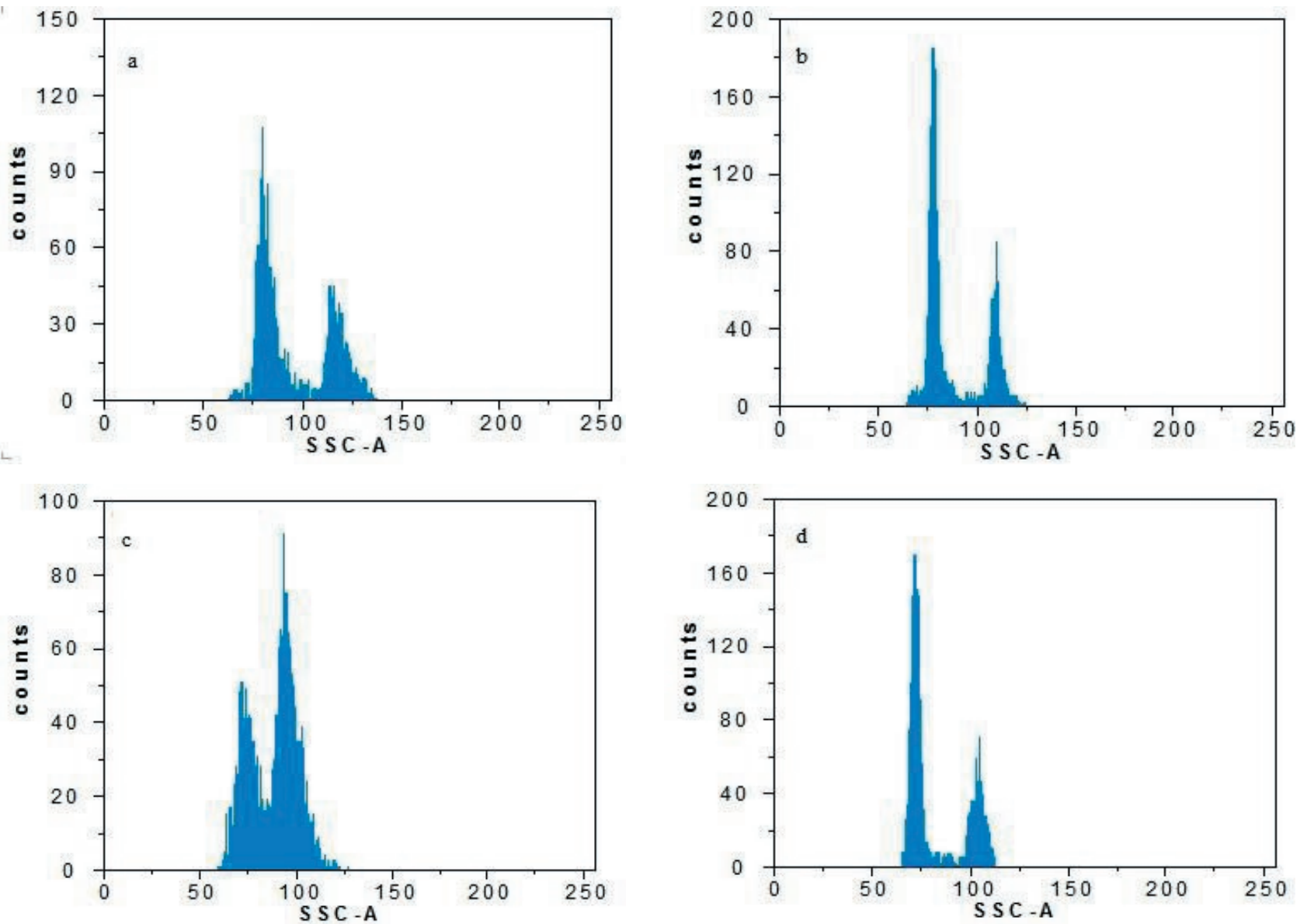

Figure 4. The histogram for analysis of theamount of nuclear DNA in leaves: The left peaks refer to the known parsley ( $P$. crispum) reference standard and right peaks to the unknown Hedera samples. a: H. hibernica $=6.23$ pg, b: H. hibernica "Deltoiedea" $=6.33$ pg, c: H. hibernica "Variegata" $=5.76 \mathrm{pg}$, d: $H$. hibernica "Hamilton" $=6.40 \mathrm{p}$.

\section{CONCLUSIONS}

Most of the recently reported new incidences of $H$. helix from the lowland of Hungary (see Bartha and Király 2015) refer to $H$. crebrescens. $H$. crebrescens is the most invasive ivy taxon in Hungary and probably most of the countries in central Europe. According to flow cytometry results, $H$. hibernica arborescence is diploid, whereas $H$. hibernica is tetraploid. Therefore, this name is not correct for this taxon, and due to its morphological features, it is probably a subspecies of $H$. crebrescens. Studies that include species from the eastern part of the distribution range of the Hedera genus in Iran and the Caucasus (formerly mentioned by K. Koch and G. Woronow) are necessary in order to conduct a more thorough survey of Hedera's diversity and relationships.

\section{ACKNOWLEDGEMENTS}

We would like to thank Prof. Ghasem Karimzade, the head of the Laboratory Biotechnology, Faculty of Agriculture, Tarbiat Modares University, Tehran, Iran for his technical assistance. We would also like to extend our gratitude to Prof. Jaroslav Doležel, the head of the Laboratory of Molecular Cytogenetic and Cytometry, Institute of Experimental Botany, Sokolovska' 6, 456 Olomouc, Czech Republic, for providing seeds of DNA reference standards and all his papers.

\section{REFERENCES}

Ackerfield J. 2001. Trichome morphology in Hedera (Araliaceae). Edinburgh Journal of Botany 58(2): 259-267. 
Ackerfield J, Wen J. 2002. A morphometric analysis of Hedera L. (the ivy genus, Araliaceae) and its taxonomic implications. Adansonia. 24(2):197-212.

Ackerfield J, Wen J. 2003. Evolution of Hedera (the ivy genus, Araliaceae): insights from chloroplast DNA data. International Journal of Plant Sciences. 164(4):593-602.

Barow M, Meister A. 2003. Endopolyploidy in seed plants is differently correlated to systematics, organ, life strategy and genome size. Plant, Cell \& Environment. 26(4):571-584.

Bartha D, Király G, Schmidt D, Tiborcz V, Barina Z, Csiky J, Jakab G, Lesku B, Schmotzer A, Vidéki R. 2015. Distribution atlas of vascular plants of Hungary. University of West Hungary, Sopron. 330.

Bennett M D, Bhandol P, Leitch I J. 2000. Nuclear DNA amounts in angiosperms and their modern use 807 new estimates. Annals of Botany. 86(4):859-909.

Bennett M D, Lettch I J. 1997. Nuclear DNA amounts in angiosperms 583 new estimat. Annals of Botany. 80(2):169-196.

Bényei-Himmer M, Tóth EG, Lengyel S, Pintér I, Bisztray GD. 2017. Hedera crebrescens (Araliaceae) a newly identified diploid taxon and triploid ivies from Hungary. Studia Botanica Hungarica. 48(2):225-252.

Clarke M M, Reichard S H, Hamilton CW. 2006. Prevalence of differen horticul tural taxa of ivy (Hedera spp., Araliaceae) in invading populations. Biological Invasions. 8(2):149-157.

Doležel J, Bartoš J. 2005. Plant DNA flow cytometry and estimation of nuclear genome size. Annals of Botany. 95(1):99-110.

Dolezel J, Bartos J, Voglmayr H, Greilhuber J. 2003. Nuclear DNA content and genome size of trout and human. Cytometry Part A: the journal of the International Society for Analytical Cytology. 51(2):127-128; author reply 129.

Doležel J, Greilhuber J, Suda J. 2007. Estimation of nuclear DNA content in plants using flow cytometry. Nature Protocols. 2(9):2233-2244.

Domoney C, Timmis J. 1980. Ribosomal RNA gene redundancy in juvenile and mature ivy (Hedera helix). Journal of Experimental Botany. 31(4):1093-1100.

Ekrt L, Trávníček P, Jarolimova V, Vit P, Urfus T. 2009. Genome size and morphology of the Dryopteris affinis group in Central Europe. Preslia. 81:261-280.

Green AF, Ramsey TS, Ramsey J. 2011. Phylogeny and biogeography of ivies (Hedera spp., Araliaceae), a polyploid complex of woody vines. Systematic Botany. 36(4):1114-1127.

Jacobsen P. 1954. Chromosome numbers in the genus Hedera L. Hereditas. 40(1-2):252-254.
König C, Ebert I, Greilhuber J. 1987. A DNA cytophotometric and chromosome banding study in Hedera helix (Araliaceae), with reference to differential DNA replication associated with juvenile adult phase change. Genome. 29(3):498-503.

Kron P, Suda J, Husband BC. 2007. Applications of flow cytometry to evolutionary and population biology. Annual Review of Ecology, Evolution and Systematics. 38:847-876.

Lawrence G, Schulze AE. 1942. The cultivated Hederas Gentes Herbarum. 6(3):107-173

Linnaeus C. 1753. Species Plantarum. Laurentius salvius, Stockholm, 1200 pp. 1179.

Loureiro J, Trávníček P, Rauchová J, Urfus T, Vit P, Štech M, Castro S, Suda J. 2010. The use of flow cytometry in the bios -ystematics, ecology and population biology of homoploid plants. Preslia. 82(1):3-21.

Marie D, Brown SC. 1993. A cytometeric exercise in plant DNA histograms, with 2C values for 70 species. Biology of the Cell. 78(1-2):41-51.

McAllister H, Rutherford, A. 1990. Hedera helix L. and H. hibernica (Kirchner) Bean (Araliaceae) in the British isles. Watsonia. 18:7-15.

McAllister H, Marshall R. 2017. Hedera: the complete guide. Royal Horticultural Society (RHS).

McAllister HA, Rutherford A. 1983. The species of ivies. Ivy Journal. 9:45-54.

Metcalfe DJ. 2005. Hedera helix L. Journal of Ecology. 93(3):632-648.

Obermayer R, Greilhuber J. 2000. Genome size in Hedera helix L. a clarification. Caryologia. 53(1):1-4.

Polito VS, Alliata V. 1981. Growth of calluses derived from shoot apical meristems of adult and juvenile English ivy (Hedera helix L.). Plant Science Letters. 22(4):387-393.

Ramsey J. 2007. Unreduced gametes and neopolyploids in natural populations of Achillea borealis (Asteraceae). Heredity. 98(3):143-150.

Reichard S. 2000. Hedera helix. Invasive plants of California wildlands University of California Press, Berkeley, California, USA.212-216.

Rose PQ. 1996. The gardener's guide to growing ivies. Timber Press.

Rutherford A, McAllister H, Mill R. 1993. New ivies from the Mediterranean area and Macaronesia. Plantsman (United Kingdom). 15:115-128.

Sharma AK, Sharma A. 1999. Plant chromosomes. Harwood Academic Amsterdam.

Stace CA. 2000. Cytology and cytogenetics as a fundamental taxonomic resource for the 20th and 21st centuries. Taxon. 49(3):451-477.

Udvardy L, Bényei-Himmer M. 1999. Escape of Irish ivy 
(Hedera hibernica as a woody evergreen weed. Publications of the Horticultural and Food Industry University. 59:161-164.

Valcárcel V, Vargas P. 2010. Quantitative morphology and species delimitation under the general lineage concept: Optimization for Hedera (Araliaceae). American Journal of Botany. 97(9): 1555-1573.

Vargas P, McAllister HA, Morton C, Jury SL, Wilkinson MJ. 1999. Polyploid speciation in Hedera (Araliaceae): Phylogenetic and biogeographic insights based on chromosome counts and ITS sequences. Plant Systematics and Evolution. 219(3-4):165-179.

Yi T, Lowry PP, Plunkett GM, Wen J. 2004. Chromosomal evolution in Araliaceae and close relatives. Taxon. 53(4):987-1005

Zonneveld B, Leitch I, Bennett M. 2005. First nuclear DNA amounts in more than 300 angiosperms. Annals of Botany. 96(2):229-244. 